\title{
International Energy Foundation (IEF) Headquarters Move to Geneva
}

$\mathrm{T}$ he International Energy Foundation was started just a few years ago, but its origins go back to 1979, which is when an international energy forum called Energex was conceived. The objective was to provide a mechanism for energy researchers, business leaders, and government representatives, from all nations and all 'areas' of energy, to get together. The goal was to provide participants from around the world with an opportunity to discuss technical, economic, and human, aspects of energy-related matters, and how developed nations could assist emerging nations in the development of their energy resources.

The first Energex forum was held in Regina, Saskatchewan, Canada, in 1982. It was a technical conference and an exposition in which 50 countries participated. Impressed by the success of that first conference, delegates unanimously approved another such event.

Two years later, the second Energex Conference was held, once again in Regina. That year, delegates from 60 countries attended. They recommended that the Energex Secretariat arrange for future forums to be held in various centres around the world. And so, in 1988, Energex ' 88 was held in Tripoli, Libya. On the recommendation of the delegates to that conference, a formal body known as the International Energy Foundation (IEF) was established. The Energex Secretariat set up an interim Board of Directors, and the IEF was officially inaugurated on 26 March 1989.

Regina and Tripoli both met the IEF's initial needs, but the Board realized that, as the organization grew and developed, a truly international setting was needed - that the IEF headquarters should be in a place where world agendas are set, multinational treaties are negotiated, and international conflicts are settled. Accordingly Geneva, Switzerland, was selected.

The Canton of Geneva is an ideal location for the IEF. It is the home or centre of what must be by far the world's greatest agglomeration of nongovernmental and United Nations bodies related to energy and/or the environment. Airlines link Geneva to all parts of the world, and topnotch communications facilities make it possible for the IEF to keep in touch with its world-wide, broadly-based membership,

The IEF Board is composed of prominent energy researchers and representatives from industry and government from India, Canada, Egypt, Brazil, Swaziland, the United States, the United Kingdom, Pakistan, and Switzerland. IEF's advisory committee has a membership of 21 . In all, 23 countries have participated in the decision-making process and evolution of IEF.

The Energex forums continue to be the official conferences of the International Energy Foundation. The latest to date, Energex '91, was held in Puerto Rico. Future meetings will be in Seoul, Korea (1993), Shanghai, China (1996), Bahrain (1998), and Geneva (AD 2000).

PETER J. CATANIA, Chairman
International Energy Foundation
3 rd Floor West
2025 Victoria Avenue
Regina
Saskatchewan S4P OSI
Canada.

Peter J. Catania, Chairman 3rd Floor West 2025 Victoria Avenue Saskatchewan S4P OSI Canada.

\section{Further Report on the Surrey Docks City Farm in London, England}

$\mathrm{T}^{\mathrm{s}}$ he following short Report tells of developments at the Surrey Docks City Farm, London, since March 1992, when a longer Report was published in the Spring issue of this Journal (Vol. 19, Nr 1, pp. 73-4, 3 figs, 1992).

As a result of a sustained campaign and local support, the Surrey Docks City Farm continues to exist as an educational and social resource. It was an enormous relief when Southwark Borough Council ultimately agreed to take over responsibility for core funding of the Farm. Thus at present the Council provides over half the costs of running the Farm and supporting its activities. But alas, local authority cuts are now threatened once again, so that this support is thrown into doubt; the struggle goes on, with a continued vigorous campaign to raise money.

Meanwhile all the activities are carried on with enthusiasm. Schools continue to attend; and just as they are now having to accommodate many changes in their management and organization, so the Farm too has to adapt to meet new needs and different demands. An enterprise entitled 'New Leaf' will provide training in horticulture over a three-years' period for people with learning difficulties, this being financed by a separate charitable grant.

There are plans for improved provision for the animals, including a new pigsty, chick-rearing houses, etc., while electricity is provided for lighting in the 'Segal' building by a windmill on the Farm and by solar panels. A young teacher, Kevin Herlichy, who worked for some years with children on the Farm, has now gone to India in the hope of making links with small farmers there.

Very successful festivals have been held at the Farm during the past year - a Harvest Fair in the Autumn, and most recently the Christmas Fair. On a gloomy, threatening day in December, the Farm was alive with activity, as people poured in from all around - children and adults coming to enjoy the fun and games, with the diversion of craftsmen at work, and to see the animals in the yard and in their warm strawy barns. There were carol-singing and good food in the café, and Christmas trees and Christmas cards for sale; while the afternoon was crowned with the illumination of the Christmas trees by the Farm's own windmill power (switched on by the local Member of Parliament, Simon Hughes). The next moment the heavens opened and rain poured down.
JOYCE ANSTEY
19 Ballast Quay
London SE10 9PD, and
Surrey Docks Farm
Rotherhithe Street
London SEI6 IEY
England, $U K$.
Tel (071) 2311010 